\title{
Monitoring dan Evaluasi Hasil Pemugaran Gapura Royal Palace Angkor Thom Kamboja (Tahap I)
}

\author{
Nahar Cahyandaru, dkk. \\ Balai Konservasi Borobudur \\ email: nhrcahyandaru@yahoo.com
}

\begin{abstract}
Abstrak: Pemerintah Indonesia pernah berperan dalam pelestarian cagar budaya di tingkat internasional, yaitu melalui misi ITASA (The Indonesian Technical Assistance for Safeguarding Angkor) untuk melakukan pemugaran di kompleks Royal Palace Angkor Thom Kamboja. Program ini berjalan dengan sukses karena berhasil menyelesaikan pemugaran tiga gapura (1995-2000). Kesuksesan program ini karena menerapkan teknologi lokal yang digabungkan dengan pengalaman pemugaran di Indonesia, serta melibatkan masyarakat lokal sebagai bentuk transfer pengetahuan dan teknologi (Sedyawati, dkk, 2000). Keberhasilan ini perlu dimonitor dan dievaluasi sebagai pertimbangan untuk melaksanakan kembali proyek serupa untuk meningkatkan peran Indonesia di tingkat regional.

Metode yang dilakukan dalam kegiatan monitoring dan evaluasi hasil pemugaran Gapura Royal Palace Angkor Thom Kamboja ini adalah survei lapangan untuk mendata kondisi kerusakan dan pelapukan pada bangunan yang telah dipugar dalam proyek ITASA. Untuk mengetahui persepsi dan apresiasi mengenai proyek yang pernah dilaksanakan, serta harapan tindak lanjut maka dilakukan survei responden dan kunjungan ke APSARA Autority. Selain itu juga dilakukan beberapa kunjungan ke beberapa proyek internasional yang sedang berjalan.

Kesimpulan yang dapat diambil dari kajian ini adalah hasil pemugaran Indonesia melalui proyek ITASA yang telah berumur kurang lebih 15 tahun saat ini masih dalam kondisi yang baik. Beberapa permasalahan yang terjadi masih dalam batas yang wajar karena material candi yang memiliki kerentanan dalam kondisi lingkungan yang ada. Tingkat pengetahuan masyarakat kamboja dan staf APSARA terhadap proyek yang pernah dilaksanakan Indonesia cukup baik, sedangkan wisatawan asing sangat rendah. Sistem informasi yang ada perlu ditingkatkan untuk memberikan informasi kepada penunjung secara efektif. Secara umum masyarakat dan wisatawan memberikan apresiasi yang cukup baik terhadap hasil pemugaran oleh Indonesia. Dukungan terhadap bantuan internasional pada pemugaran situs-situs di Angkor termasuk oleh Indonesia cukup tinggi. Proyek pelestarian yang dilaksanakan oleh masyarakat internasional dari berbagai negara masih berlangsung secara intensif hingga saat ini. Pemerintah Kamboja dan APSARA Authority masih berharap adanya proyek dari masyarakat internasional.
\end{abstract}

\section{Kata kunci : ITASA, Evaluasi pemugaran, Gapura Royal Palace Angkor Thom}

\begin{abstract}
Indonesian government had a role in the preservation of cultural heritage at the international level, through the ITASA (The Indonesian Technical Assistance for Safeguarding Angkor) mission to restore the Royal Palace gates of Angkor Thom Cambodia. This program was successful to complete the restoration of three gates (1995-2000). This project was a success because of applying local technology in combination with the restoration experience in Indonesia, as well as involving local communities as knowledge and technology transfer program (Sedyawati, et al, 2000). This successful project needs to be monitored and evaluated for a consideration to reestablish similar projects to enhance the Indonesia role in regional level.

The method used for monitoring and evaluation of the restoration results on the Royal Palace gates, Angkor Thom, Cambodia is field survey to assess the damage and weathering conditions in buildings that have been restored in the ITASA project. Survey to respondents and visit to Apsara Autority were conducted to know the perception and appreciation of the project that have been undertaken, as well as the expectations of follow-up. It also conducted several visits to international projects that are still on-going.

The conclusion that can be drawn from this study is that the restoration result by Indonesia through ITASA project, which has been aged less than 15 years, is still in good condition. Some problems occurred is still within reasonable limits as material temples have vulnerabilities in the existing environmental conditions. The level of public knowledge of Cambodian and APSARA staff to the project ever undertaken Indonesia is quite good, while for the foreign tourists, it is very low. Existing information system needs to be improved to provide effective information system to visitors. In general, the public and tourists give a fairly good appreciation of the restoration results by Indonesia. Support for international assistance in the sites restoration in the Angkor including by Indonesia is quite high. Preservation projects implemented by the international community of various countries are still on-going intensively. The Government of Cambodia and the APSARA Authority still hopes the projects from international community.
\end{abstract}

Keywords: ITASA, Restoration evaluation, Royal Palace Gate of Angkor 


\section{LATAR BELAKANG}

Indonesia merupakan negara yang menganut asas politik luar negeri bebas aktif. Dengan asas politik bebas maka Indonesia tidak memihak pada satu blok dan dapat bekerja sama dengan semua negara. Salah satu negara tetangga yang memiliki hubungan baik adalah Kamboja. Hubungan baik dengan Kamboja terjalin karena faktor historis dan budaya, serta politik luar negeri kedua negara yang sejalan. Kerjasama dengan Kamboja juga memiliki nilai strategis secara ekonomi karena Kamboja dan Indonesia sama-sama mengembangkan pariwisata berbasis kekayaan budaya. Dengan kerjasama yang terjalin, maka dapat meningkatkan daya tarik dan promosi kedua negara untuk mendatangkan wisatawan mancanegara. Dengan kesadaran ini, maka berbagai program kerjasama telah terjalin dengan baik selama ini.

Menurut catatan sejarah, sejak awal millenium pertama tarikh Masehi, bangsa-bangsa di Asia Tenggara telah menjalin hubungan ekonomi, religi, dan akhirnya politik. Dimulai dari hubungan perdagangan kemudian disusul dengan hubungan keagamaan dan politik antar kerajaan-kerajaan. Adanya hubungan antar samudera dan antar benua, ternyata telah menimbulkan kesejajaran di dalam pertumbuhan sejarah kerajaan-kerajaan di Asia Tenggara. Pada sekitar abad ke-7 Masehi, di wilayah Kamboja terdapat Kerajaan Chen-la dengan rajanya Jayawarman I (650-681). Ia adalah seorang raja yang mahir dalam peperangan. Sumber Tionghoa menyebutkan bahwa pada tahun 650-656 raja ini menyerbu kerajaan di Laos. Selain kuat dalam peperangan, Chen-la juga kuat dalam perdagangan dan pelayaran. Kota pelabuhannya yang terkenal pada waktu itu adalah Oc-eo. Melalui pelabuhan ini komoditi perdagangan disalurkan ke tempat-tempat lain (Utomo, 2013).

Menurut lazimnya, sejarah kuno khmer dibagi menjadi tiga jaman : Jaman Funan dari permulaan tarikh Masehi sampai pertengahan abad ke-IV, Jaman Chenla dari pertengahan abad ke-IV sampai tahun 802, dan Jaman Angkor dari tahun 802 sampai 1431. Jaman Angkor dibuka oleh Raja Jayawarman II, yang pemerintahannya dapat diketahui dari prasasti Sdok Kak Thom. Dari prasasti tersebut dapat diketahui, bahwa Raja Jayawarman II mengadakan upacara besar di atas Gunung Mahendra untuk menyatakan kemerdekaan negaranya, terlepas dari kekuasaan Jawa, dan menetapkan dirinya sebagai satu- satunya Cakrawartin di Kambujadeca. Pada kesempatan tersebut diadakan pula upacara khusus untuk meresmikan didirikannya dewaraja (Soekmono, 1974).

Adanya kedekatan sejarah ini pula yang mendorong kerja sama antar negara saat ini. Program kerjasama yang pernah berjalan dengan baik, adalah misi ITASA (The Indonesian Technical Assistance for Safeguarding Angkor) untuk melakukan pemugaran di kompleks Angkor Thom. Misi ini merupakan kontribusi Indonesia setelah mampu melakukan pemugaran Candi Borobudur pada tahun 1973-1983 dengan sukses. Tenaga terampil yang terlibat pada pemugaran Candi Borobudur menjadi tim yang memimpin pemugaran sekaligus untuk transfer pengalaman. Program ini berjalan dengan sukses karena berhasil menyelesaikan pemugaran dua gapura Royal Palace tahun 1995-2000. Kesuksesan program ini karena menerapkan teknologi lokal yang digabungkan dengan pengalaman pemugaran Candi Borobudur. Pelaksanaan pemugaran melibatkan masyarakat lokal sekaligus sebagai bentuk transfer pengetahuan (Sedyawati, dkk, 2000).

Model pemugaran yang dilakukan oleh Indonesia dengan pelibatan aktif masyarakat lokal mendapatkan sambutan positif dan menjadi perhatian negara-negara lain yang memiliki program bantuan di Kamboja. Saat ini model pelibatan masyarakat dan peningkatan kapasitas dalam pelestarian menjadi strategi utama di dunia. Prestasi Indonesia dalam program ITASA dengan keberhasilan pemugaran dua gapura Royal Palace mendapat apresiasi positif dari Kamboja dan berbagai pihak. Oleh karena itu sudah selayaknya jika direncanakan kembali program serupa di Kamboja sebagai kelanjutan kerjasama yang telah terjalin dengan sangat baik. Program yang penting untuk direncanakan ke depan adalah melakukan kembali kegiatan technical asistant untuk pemugaran atau konservasi di situs-situs penting kawasan Angkor.

Selain pengalaman keberhasilan program ITASA, kerjasama penting untuk dilakukan karena saat ini Indonesia dan Kamboja telah mengikat kerjasama bilateral di bidang budaya dan pariwisata. Kerja sama tersebut diawali dengan kerangka kerja sama Trail of Civilization yang melibatkan beberapa negara Asia Tenggara yang memiliki kedekatan budaya, termasuk Kamboja. Setelah kerja sama tersebut, Indonesia dan Kamboja semakin mempererat kerja sama dalam 
kerangka sister temple. Kerja sama sister temple tersebut telah disepakati oleh Pemerintah Provinsi Jawa Tengah dan Pemerintah Provinsi Siem Reap. Dengan adanya kerjasama tersebut maka sudah semestinya diikuti dengan program-program lain yang berkaitan dengan pelestarian dua situs, yaitu Borobudur dan Angkor.

Sebagai langkah awal untuk melanjutkan kembali program technical assistant Indonesia di Kamboja, maka perlu dilakukan monitoring dan evaluasi terhadap hasil pekerjaan oleh ITASA pada 1995-2000. Secara umum pemugaran tersebut telah diakui keberhasilannya, namun perlu langkah evaluasi untuk mengetahui kekuatan dan keberhasilannya sehingga dapat dikembangkan pada perencanaan ke depan. Di sisi lain perlu dievaluasi adanya kekurangan atau kelemahan yang ada, sehingga dapat diminimalkan untuk perencanaan dan kemungkinan perlunya tindakan perbaikan.

Kunjungan ke Kamboja terutama diarahkan pada evaluasi hasil pemugaran dan mengembangkan sistem monitoring pada situs. Kunjungan ini akan mengambil data teknis secara langsung, observasi lapangan, dan survey terhadap hasil pemugaran. Kunjungan ini diharapkan memiliki manfaat yang besar bagi evaluasi hasil pekerjaan Pemerintah Indonesia di Kamboja, sekaligus untuk menjadi dasar penyusunan rencana kerja sama ke depan apabila dimungkinkan untuk dilaksanakan kembali. Masalah yang dirumuskan dalam kajian ini adalah bagaimana kondisi kerusakan dan pelapukan bangunan yang telah dipugar setelah kurang lebih 15 tahun yang lalu. Selanjutnya adalah perlu mengetahui tingkat keberhasilan pemugaran secara objektif melalui survei persepsi sekaligus menyerap informasi mengenai program ke depan. Untuk perencanaan lebih lanjut maka permasalahan yang dirumuskan adalah bagaimana kondisi proyek-proyek dari negara lain yang hingga saat ini masih berlangsung.

\section{METODE}

Metode yang dilakukan dalam kegiatan monitoring dan evaluasi hasil pemugaran Gapura Royal Palace Angkor Thom Kamboja (Tahap I) adalah

1. Survei lapangan untuk mendata kondisi kerusakan dan pelapukan bangunan yang telah dipugar dalam proyek ITASA tahun 1995-2000.

2. Kuisioner survei untuk mengambil data kepada responden.

3. Kunjungan ke APSARA Authority

4. Kunjungan ke beberapa proyek yang sedang berjalan

5. Diskusi hasil monitoring dan evaluasi Pemugaran Gapura Royal Palace Angkor Thom Kamboja (Tahap I) dengan mengundang berbagai pemangku kebijakan antara lain Dirjen Kebudayaan, Direktur PCBM, Direktur INDB, Direktur PT.TWCBP, Eks Proyek ITASA, BPCB DIY dan BPCB Jawa Tengah.

\section{DATA DAN PEMBAHASAN}

\section{A. Observasi Kondisi Fisik Hasil Pemugaran ITASA}

Observasi dilaksanakan dengan cara survei langsung pada bangunan gapura dan mendata kondisi kerusakan dan pelapukannya. Parameter kerusakan dan pelapukan yang disurvei meliputi pertumbuhan biologi, penggaraman, kerapuhan, kerusakan struktur, retakan, kerusakan batu. Pendataan dilakukan dengan menghitung jumlah kerusakan secara langsung, sedang untuk pertumbuhan organisme dihitung secara perkiraan luas permukaan yang ditumbuhi dalam persen. Hasil yang diperoleh disajikan dalam Tabel 1 sebagai berikut.

Berdasarkan data pada tabel 1, dapat diketahui

Tabel 1. Hasil Observasi Kerusakan dan Pelapukan Gapura Royal Palace Angkor Thom

\begin{tabular}{|c|c|c|c|c|c|}
\hline \multirow{2}{*}{ No } & \multirow{2}{*}{$\begin{array}{l}\text { Lokasi Pintu } \\
\text { Gerbang }\end{array}$} & \multirow{2}{*}{ Bidang } & \multicolumn{2}{|c|}{ Bagian } & \multirow{2}{*}{ Bagian Bilik } \\
\hline & & & Luar & Dalam & \\
\hline \multirow{3}{*}{1} & \multirow{3}{*}{ Selatan } & A & $\begin{array}{l}M=30 \% \\
B=7 \\
C=0 \\
E=0,25\end{array}$ & $\begin{array}{l}M=40 \% \\
B=17 \\
C=16 \\
E=1\end{array}$ & $\begin{array}{l}M=10 \% \\
B=10 \\
C=3 \\
E=4,5\end{array}$ \\
\hline & & B & $\begin{array}{l}M=25 \% \\
B=35 \\
C=19 \\
E=0,8\end{array}$ & $\begin{array}{l}M=20 \% \\
B=11 \\
C=28 \\
E=2\end{array}$ & $\begin{array}{l}M=2 \% \\
B=15 \\
C=15 \\
E=3,5\end{array}$ \\
\hline & & C & $\begin{array}{l}M=30 \% \\
B=2 \\
C=1 \\
E=3\end{array}$ & $\begin{array}{l}M=15 \% \\
B=7 \\
C=16 \\
E=0,7\end{array}$ & \\
\hline
\end{tabular}




\begin{tabular}{|c|c|c|c|c|c|}
\hline \multirow{7}{*}{2} & \multirow{7}{*}{ Timur } & $A$ & $\begin{array}{l}M=5 \% \\
B=1 \\
C=8 \\
E=3,6\end{array}$ & $\begin{array}{l}M=30 \% \\
B=8 \\
C=2 \\
E=2\end{array}$ & $\begin{array}{l}M=80 \% \\
B=9 \\
C=2 \\
E=1,9\end{array}$ \\
\hline & & B & $\begin{array}{l}M=10 \% \\
B=1 \\
C=8 \\
E=1,7 \\
\text { Penggaraman }=10 \%\end{array}$ & $\begin{array}{l}M=50 \% \\
B=5 \\
C=11 \\
E=0,6\end{array}$ & $\begin{array}{l}M=- \\
B=4 \\
C=3 \\
E=2\end{array}$ \\
\hline & & C & $\begin{array}{l}M=5 \% \\
B=7 \\
C=3 \\
E=0,9\end{array}$ & $\begin{array}{l}M=40 \% \\
B=8 \\
C=6 \\
E=0,9\end{array}$ & $\begin{array}{l}M=80 \% \\
B=5 \\
C=1 \\
E=4,5\end{array}$ \\
\hline & & $\mathrm{D}$ & $\begin{array}{l}M=1 \% \\
B=6 \\
C=1 \\
E=2\end{array}$ & $\begin{array}{l}M=30 \% \\
B=8 \\
C=4 \\
E=2,4\end{array}$ & $\begin{array}{l}M=30 \% \\
B=8 \\
C=6 \\
E=0,7 \\
\text { Penggaraman }=5 \%\end{array}$ \\
\hline & & $E$ & $\begin{array}{l}M=5 \% \\
B=3 \\
C=1 \\
E=0,5\end{array}$ & $\begin{array}{l}M=40 \% \\
B=5 \\
C=3 \\
E=1,9\end{array}$ & $\begin{array}{l}M=10 \% \\
B=13 \\
C=3 \\
E=2,3 \\
\text { Penggaraman }=5 \%\end{array}$ \\
\hline & & $\mathrm{F}$ & $\begin{array}{l}M=6 \% \\
B=2 \\
C=1 \\
E=0,3\end{array}$ & $\begin{array}{l}M=30 \% \\
B=6 \\
C=2 \\
E=2\end{array}$ & $\begin{array}{l}M=10 \% \\
B=1 \\
C=5 \\
E=0,1\end{array}$ \\
\hline & & G & $\begin{array}{l}M=20 \% \\
B=1 \\
C=4 \\
E=0,8\end{array}$ & $\begin{array}{l}M=40 \% \\
B=18 \\
C=5 \\
E=4,6\end{array}$ & $\begin{array}{l}M=10 \% \\
B=5 \\
C=3 \\
E=0,4 \\
\text { Penggaraman }=10 \%\end{array}$ \\
\hline & \multirow{3}{*}{ Utara } & $A$ & $\begin{array}{l}\text { Mikroorganisme, } \\
L=25 \% \\
A=80 \% \\
O=5 \% \\
B=0 \\
C=3 \\
E=5 \\
S=1\end{array}$ & $\begin{array}{l}\text { Mikroorganisme, } \\
L=30 \% \\
A=80 \% \\
O=5 \% \\
B=0 \\
C=0 \\
E=2\end{array}$ & \\
\hline & & B & $\begin{array}{l}\text { Mikroorganisme, } \\
L=15 \% \\
A=75 \% \\
O=3 \% \\
B=1 \\
C=4 \\
E=11\end{array}$ & $\begin{array}{l}\text { Mikroorganisme, } \\
L=25 \% \\
A=70 \% \\
O=5 \% \\
B=0 \\
C=0 \\
E=3\end{array}$ & \\
\hline & & C & $\begin{array}{l}\text { Mikroorganisme, } \\
L=25 \% \\
A=75 \% \\
O=3 \% \\
B=1 \\
C=2 \\
E=5\end{array}$ & $\begin{array}{l}\text { Mikroorganisme, } \\
L=25 \% \\
A=75 \% \\
O=3 \% \\
B=0 \\
C=0 \\
E=4\end{array}$ & \\
\hline \multicolumn{3}{|c|}{$\begin{array}{l}\text { Keterangan : } \\
M=\text { Mikroorganisme }(\%) \\
L=\text { Lumut } \\
A=\text { Algae } \\
O=\text { Organisme }\end{array}$} & $\begin{aligned} \mathrm{B} & =\text { Pecah (blok) } \\
\mathrm{C} & =\text { Retak (Jumlah) } \\
\mathrm{E} & =\text { Pengelupasan }\left(\mathrm{m}^{2}\right) \\
\mathrm{S} & =\text { Struktural/Geser }\end{aligned}$ & & \\
\hline
\end{tabular}

bagaimana kondisi ketiga gapura tersebut. Gapura tersebut telah selesai dipugar sekitar 15 tahun yang lalu. Setelah pemugaran tidak dilakukan pemeliharaan yang intensif, namun hanya pembersihan sederhana. Meskipun demikian secara umum, kondisi ketiga gapura masih baik, tidak terdapat kerusakan atau pelapukan yang serius.

Pelapukan yang umum terjadi adalah pertumbuhan organisme, namun hal ini tidak terlalu membahayakan mengingat kondisi lingkungan yang ada dan dampak yang diakibatkan tidak terlalu fatal.
Beberapa batu mengalami retakan dan kerapuhan namun masih dalam batas yang aman dan tidak membahayakan struktur. Dalam tindakan konservasi ke depan, hal ini dapat diatasi dengan berbagai metode yang saat ini telah berkembang.

\section{B. Survei Responden Terhadap Proyek Itasa}

Hasil survei terhadap responden ini bertujuan untuk mendapatkan informasi mengenai proyek ITASA yang dahulu pernah dilaksanakan. Survei ini diperlukan 
karena proyek telah dilaksanakan cukup lama, sehingga perlu digali kembali secara objektif. Selain itu survei juga sangat bermanfaat untuk mengevaluasi efektivitas sarana informasi yang ada di lokasi saat ini. Survei yang dilakukan telah berhasil menjaring 82 responden dari berbagai latar belakang. Dalam pembahasan dikelompokkan ke dalam 3 kelompok, yaitu pegawai APSARA Authority, masyarakat lokal, dan turis asing. Profil dari masing-masing responden dapat dilihat pada Tabel 2 berikut.

Tabel 2. Profil Responden Survey

\begin{tabular}{|c|c|c|c|c|c|}
\hline DOMISILI/POSISI & Resp & NAMA & (Tahun) & PEKERJAAN & JENIS KELAMIN \\
\hline Staff & 1 & Srun tech & - & Staff Apsara & Laki-laki \\
\hline \multirow[t]{17}{*}{ APSARA Authority } & 2 & Norng Borouy & $30-40$ & Staff Apsara & Perempuan \\
\hline & 3 & So Pot & $30-40$ & Sala Kanseng Village & Laki-laki \\
\hline & 4 & Pisei & $20-30$ & Staff Apsara & Perempuan \\
\hline & 5 & Aim Socheata & $30-40$ & Staff Apsara & Perempuan \\
\hline & 6 & Sorithy & $40-50$ & Karyawan & Laki-laki \\
\hline & 7 & Thea & $50-60$ & Staff Apsara & Laki-laki \\
\hline & 8 & Meng & $40-50$ & Staff Apsara & Laki-laki \\
\hline & 9 & Nang & $30-40$ & Staff Apsara & Perempuan \\
\hline & 10 & Ten Van & $30-40$ & Staff Teknik & Laki-laki \\
\hline & 11 & Dara & $30-40$ & Staff Apsara & Laki-laki \\
\hline & 12 & Rachana & $30-40$ & Staff Apsara & Laki-laki \\
\hline & 13 & Soy Kim Hean & $20-30$ & Staff Apsara & Perempuan \\
\hline & 14 & Mony & $40-50$ & Staff Teknik & Laki-laki \\
\hline & 15 & Chan Chhorvy & $20-30$ & Staff Apsara & Perempuan \\
\hline & 16 & Kin Sengpheakjey & $20-30$ & Staff Apsara & Perempuan \\
\hline & 17 & Kim Hul & $40-50$ & Staff Apsara & Laki-laki \\
\hline & 18 & Srey Socheata & $30-40$ & Staff Apsara & Perempuan \\
\hline Penduduk lokal & 19 & Noum Long & $40-50$ & Pekerja Proyek Apsara & Laki-laki \\
\hline \multirow{4}{*}{ (Sekitar Preah Ko) } & 20 & Saem Sea & $40-50$ & Pekerja Proyek Apsara & Laki-laki \\
\hline & 21 & Saem Sieng & $40-50$ & Pekerja Proyek Apsara & Laki-laki \\
\hline & 22 & Saem Oeam & $>60$ & Pekerja Proyek Apsara & Laki-laki \\
\hline & 23 & Phem Phoem & $>60$ & Pekerja Proyek Apsara & Laki-laki \\
\hline Penduduk lokal & 24 & Ngin Thy & $50-60$ & Pekerja/ juru pelihara & Laki-laki \\
\hline (Sekitar Ware Kit & 25 & Son & $50-60$ & Pedagang & Perempuan \\
\hline \multirow[t]{7}{*}{ Royal Palace) } & 26 & Beay & $40-50$ & Penjaga/keamanan & Perempuan \\
\hline & 27 & Sek & $>60$ & Penjaga/keamanan & Perempuan \\
\hline & 28 & Dany & $30-40$ & Staff Apsara & Perempuan \\
\hline & 29 & Chum Noa & $20-30$ & Pekerja Proyek Apsara & Laki-laki \\
\hline & 30 & Pheakdea & $20-30$ & Staff Apsara & Laki-laki \\
\hline & 31 & Ceou Enc & $20-30$ & Staff Apsara & Perempuan \\
\hline & 32 & Cham Nan & $20-30$ & Staff Apsara & Perempuan \\
\hline Penduduk lokal & 33 & Vat Sruch & $40-50$ & Pekerja proyek Apsara & Laki-laki \\
\hline (Proyek Ta Phrom & 34 & Cheang Choen & $20-30$ & Pekerja proyek Apsara & Laki-laki \\
\hline \multirow[t]{5}{*}{ APSARA-India) } & 35 & Cheng Ann & $20-30$ & Pekerja proyek Apsara & Laki-laki \\
\hline & 36 & Chat Chien & $20-30$ & Pekerja proyek Apsara & Laki-laki \\
\hline & 37 & liem Long & $30-40$ & Pekerja proyek Apsara & Laki-laki \\
\hline & 38 & Saem Chanthol & $20-30$ & Pekerja proyek Apsara & Laki-laki \\
\hline & 39 & Phun Phoen & $30-40$ & Pekerja proyek Apsara & Laki-laki \\
\hline
\end{tabular}




\begin{tabular}{|c|c|c|c|c|c|}
\hline & 40 & Saem Norm & $30-40$ & Pekerja proyek Apsara & Laki-laki \\
\hline & 41 & Thorn Vor & $30-40$ & Pekerja proyek Apsara & Laki-laki \\
\hline Penduduk lokal & 42 & $\operatorname{Sim} A i$ & $>60$ & Pekerja & Laki-laki \\
\hline \multirow[t]{14}{*}{ (Sekitar Bakong) } & 43 & Sith & $40-50$ & Pekerja & Laki-laki \\
\hline & 44 & Sophea & $30-40$ & Penjual & Perempuan \\
\hline & 45 & Heng & $10-20$ & Penjual & Perempuan \\
\hline & 46 & Phalla & $40-50$ & Turis lokal/Penjual & Laki-laki \\
\hline & 47 & Naet & $50-60$ & Pekerja & Perempuan \\
\hline & 48 & Hong Poy & $40-50$ & Pekerja & Laki-laki \\
\hline & 49 & Moun & $50-60$ & Penjual & Laki-laki \\
\hline & 50 & Hak & $40-50$ & Pekerja & Laki-laki \\
\hline & 51 & Mony & $40-50$ & Pekerja & Laki-laki \\
\hline & 52 & Saem Sung & $20-30$ & Pekerja & Laki-laki \\
\hline & 53 & Kham Ping & $50-60$ & Petani & Laki-laki \\
\hline & 54 & Mut Kem & $40-50$ & Pekerja & Perempuan \\
\hline & 55 & Soun & $20-30$ & Warga & Laki-laki \\
\hline & 56 & Leap & $>60$ & Warga & Perempuan \\
\hline Penduduk lokal & 57 & Su Teng Ly & $50-60$ & Pekerja & Laki-laki \\
\hline (Kok Chark Temple & 58 & Duong Rith & $50-60$ & Pekerja & Laki-laki \\
\hline Brick Restoration & 59 & Nut Poeng & $>60$ & Pekerja & Laki-laki \\
\hline \multirow[t]{7}{*}{ project APSARA) } & 60 & Tim Sok & $>60$ & Pekerja & \\
\hline & 61 & Hout Dy & $40-50$ & Pekerja & \\
\hline & 62 & Chouk Rith & $50-60$ & Pekerja & \\
\hline & 63 & Tan Sam & $30-40$ & Pekerja & \\
\hline & 64 & Ve Savoen & $30-40$ & Pekerja & \\
\hline & 65 & Muv Ra & $20-30$ & Pekerja & \\
\hline & 66 & Un Mao & $50-60$ & Pekerja & Laki-laki \\
\hline Penduduk lokal & 67 & Staff Hotel & $20-30$ & Pelajar & Perempuan \\
\hline \multirow[t]{5}{*}{ (Staff Hotel) } & 68 & Staff Hotel & $20-30$ & Pelajar & Perempuan \\
\hline & 69 & Staff Hotel & $20-30$ & Penerima tamu & Laki-laki \\
\hline & 70 & Staff Hotel & $20-30$ & Staff Hotel & Laki-laki \\
\hline & 71 & Staff Hotel & $30-40$ & Staff Hotel & Laki-laki \\
\hline & 72 & Staff Hotel & & Staff Hotel & \\
\hline Tourist & 73 & Turis China & $40-50$ & Guru & \\
\hline \multirow[t]{9}{*}{ (Wisatawan Asing) } & 74 & Turis Brasil & $30-40$ & Manager IT & Perempuan \\
\hline & 75 & Turis New Zealand & $20-30$ & Market Research & Laki-laki \\
\hline & 76 & Turis Ireland & $20-30$ & Teknisi & Perempuan \\
\hline & 77 & Turis Perancis & $30-40$ & & Perempuan \\
\hline & 78 & Turis Canada & $20-30$ & Penulis & Perempuan \\
\hline & 79 & Turis Perancis & $20-30$ & Pelatih Sky & Laki-laki \\
\hline & 80 & Turis Brasil & $30-40$ & Direktur & Perempuan \\
\hline & 81 & Turis Canada & $20-30$ & & Perempuan \\
\hline & 82 & Turis Portugal & $30-40$ & Teknisi & Laki-laki \\
\hline
\end{tabular}


Hasil survei terhadap responden tersebut dapat dilihat pada Tabel 3 berikut ini.

Tabel 3. Hasil Survei Terhadap Responden

\begin{tabular}{|c|c|c|c|c|c|c|c|c|c|c|c|c|c|c|c|c|c|c|}
\hline \multirow{2}{*}{$\begin{array}{c}\text { No. } \\
\text { Rspdn }\end{array}$} & \multicolumn{5}{|c|}{$\begin{array}{l}\text { Pengetahuan tentang Proyek } \\
\text { Indonesia }\end{array}$} & \multicolumn{7}{|c|}{ Persepsi Hasil Restorasi } & \multicolumn{5}{|c|}{ Dukungan Proyek ke Depan } & \multirow{2}{*}{ Rata-rata } \\
\hline & 1 & 2 & 3 & 4 & $\begin{array}{l}\text { Rata- } \\
\text { rata }\end{array}$ & 1 & 2 & 3 & 4 & 5 & 6 & $\begin{array}{l}\text { Rata- } \\
\text { rata }\end{array}$ & 1 & 2 & 3 & 4 & 5 & \\
\hline 2 & 4 & 4 & 4 & 2 & 2,50 & 4 & 4 & 4 & 3 & 3 & 4 & 2,89 & 4 & 4 & 4 & 4 & 4 & 3,67 \\
\hline 3 & 3 & 4 & 3 & 4 & & 3 & 3 & 3 & 3 & 3 & 3 & & 4 & 3 & 4 & 4 & 4 & \\
\hline 4 & 3 & 4 & 4 & 4 & & 3 & 4 & 4 & 3 & 3 & 3 & & 4 & 4 & 4 & 3 & 4 & \\
\hline 5 & 4 & 4 & 0 & 1 & & 3 & 3 & 4 & 2 & 2 & 4 & & 4 & 4 & 4 & 4 & 4 & \\
\hline 6 & 3 & 4 & 1 & 1 & & 3 & 3 & 3 & 3 & 2 & 4 & & 4 & 3 & 4 & 4 & 4 & \\
\hline 7 & 4 & 4 & 2 & 2 & & 3 & 3 & 2 & 2 & 2 & 3 & & 4 & 3 & 4 & 4 & 4 & \\
\hline 8 & 4 & 4 & 1 & 1 & & 4 & 4 & 3 & 3 & 1 & 4 & & 4 & 3 & 4 & 4 & 4 & \\
\hline 9 & 4 & 4 & 1 & 2 & & 4 & 4 & 4 & 4 & 2 & 3 & & 4 & 4 & 4 & 4 & 4 & \\
\hline 10 & 3 & 3 & 3 & 3 & & 4 & 4 & 3 & 3 & 3 & 3 & & 3 & 3 & 4 & 4 & 4 & \\
\hline 11 & 3 & 3 & 2 & 3 & & 3 & 4 & 3 & 4 & 3 & 2 & & 2 & 3 & 4 & 3 & 4 & \\
\hline 12 & 2 & 1 & 4 & 1 & & 2 & 3 & 3 & 3 & 3 & 2 & & 4 & 3 & 4 & 4 & 4 & \\
\hline 13 & 4 & 4 & 4 & 4 & & 4 & 4 & 4 & 4 & 3 & 3 & & 2 & 3 & 3 & 4 & 4 & \\
\hline 14 & 2 & 1 & 3 & 3 & & 2 & 2 & 3 & 3 & 2 & 2 & & 2 & 3 & 3 & 4 & 4 & \\
\hline 15 & 2 & 2 & 2 & 3 & & 2 & 3 & 4 & 3 & 3 & 3 & & 2 & 3 & 4 & 4 & 4 & \\
\hline 16 & 0 & 0 & 0 & 1 & & 0 & 0 & 0 & 0 & 0 & 4 & & 4 & 3 & 4 & 4 & 4 & \\
\hline 17 & 0 & 0 & 0 & 0 & & 0 & 0 & 4 & 0 & 0 & 4 & & 3 & 3 & 3 & 3 & 3 & \\
\hline 18 & 4 & 4 & 1 & 2 & & 4 & 4 & 4 & 3 & 3 & 4 & & 4 & 4 & 4 & 4 & 4 & \\
\hline 19 & 4 & 4 & 1 & 0 & & 3 & 3 & 3 & 2 & 3 & 4 & & 4 & 3 & 4 & 4 & 4 & \\
\hline 20 & 4 & 4 & 3 & 1 & 1,59 & 3 & 3 & 4 & 4 & 3 & 4 & 2,91 & 4 & 4 & 4 & 4 & 4 & 3,85 \\
\hline 21 & 4 & 4 & 3 & 1 & & 3 & 3 & 4 & 4 & 3 & 4 & & 4 & 4 & 4 & 4 & 4 & \\
\hline 22 & 4 & 4 & 3 & 1 & & 3 & 3 & 4 & 4 & 3 & 4 & & 4 & 4 & 4 & 4 & 4 & \\
\hline 23 & 3 & 4 & 3 & 1 & & 2 & 3 & 4 & 4 & 3 & 4 & & 4 & 4 & 4 & 4 & 4 & \\
\hline 24 & 3 & 4 & 3 & 1 & & 2 & 3 & 4 & 4 & 3 & 4 & & 4 & 4 & 4 & 4 & 4 & \\
\hline 25 & 4 & 4 & 4 & 3 & & 4 & 4 & 4 & 4 & 3 & 4 & & 4 & 3 & 4 & 4 & 4 & \\
\hline 26 & 4 & 4 & 4 & 3 & & 4 & 4 & 4 & 4 & 3 & 4 & & 4 & 3 & 4 & 4 & 4 & \\
\hline 27 & 4 & 4 & 4 & 3 & & 4 & 4 & 4 & 4 & 3 & 4 & & 4 & 3 & 4 & 4 & 4 & \\
\hline 28 & 4 & 4 & 4 & 3 & & 4 & 4 & 4 & 4 & 3 & 4 & & 4 & 4 & 4 & 4 & 4 & \\
\hline 29 & 4 & 4 & 4 & 3 & & 4 & 4 & 4 & 4 & 3 & 4 & & 4 & 4 & 4 & 4 & 4 & \\
\hline 30 & 4 & 4 & 4 & 3 & & 4 & 4 & 4 & 4 & 3 & 4 & & 4 & 4 & 4 & 4 & 4 & \\
\hline 31 & 4 & 4 & 4 & 3 & & 4 & 4 & 4 & 4 & 3 & 4 & & 4 & 4 & 4 & 4 & 4 & \\
\hline 32 & 4 & 4 & 4 & 3 & & 4 & 4 & 4 & 4 & 3 & 4 & & 4 & 4 & 4 & 4 & 4 & \\
\hline 33 & 4 & 4 & 4 & 3 & & 4 & 4 & 4 & 4 & 3 & 4 & & 4 & 4 & 4 & 4 & 4 & \\
\hline 34 & 0 & 0 & 0 & 0 & & 3 & 3 & 3 & 2 & 3 & 4 & & 4 & 4 & 4 & 4 & 4 & \\
\hline 35 & 0 & 0 & 0 & 0 & & 3 & 3 & 3 & 2 & 3 & 4 & & 4 & 4 & 4 & 4 & 4 & \\
\hline 36 & 0 & 0 & 0 & 0 & & 3 & 3 & 3 & 2 & 3 & 4 & & 4 & 4 & 4 & 4 & 4 & \\
\hline 37 & 0 & 0 & 0 & 0 & & 3 & 3 & 3 & 2 & 3 & 4 & & 4 & 4 & 4 & 4 & 4 & \\
\hline 38 & 0 & 0 & 0 & 0 & & 3 & 3 & 3 & 2 & 3 & 4 & & 4 & 4 & 4 & 4 & 4 & \\
\hline 39 & 0 & 0 & 0 & 0 & & 3 & 3 & 3 & 2 & 3 & 4 & & 4 & 4 & 4 & 4 & 4 & \\
\hline 40 & 0 & 0 & 0 & 0 & & 3 & 3 & 3 & 2 & 3 & 4 & & 4 & 4 & 4 & 4 & 4 & \\
\hline
\end{tabular}




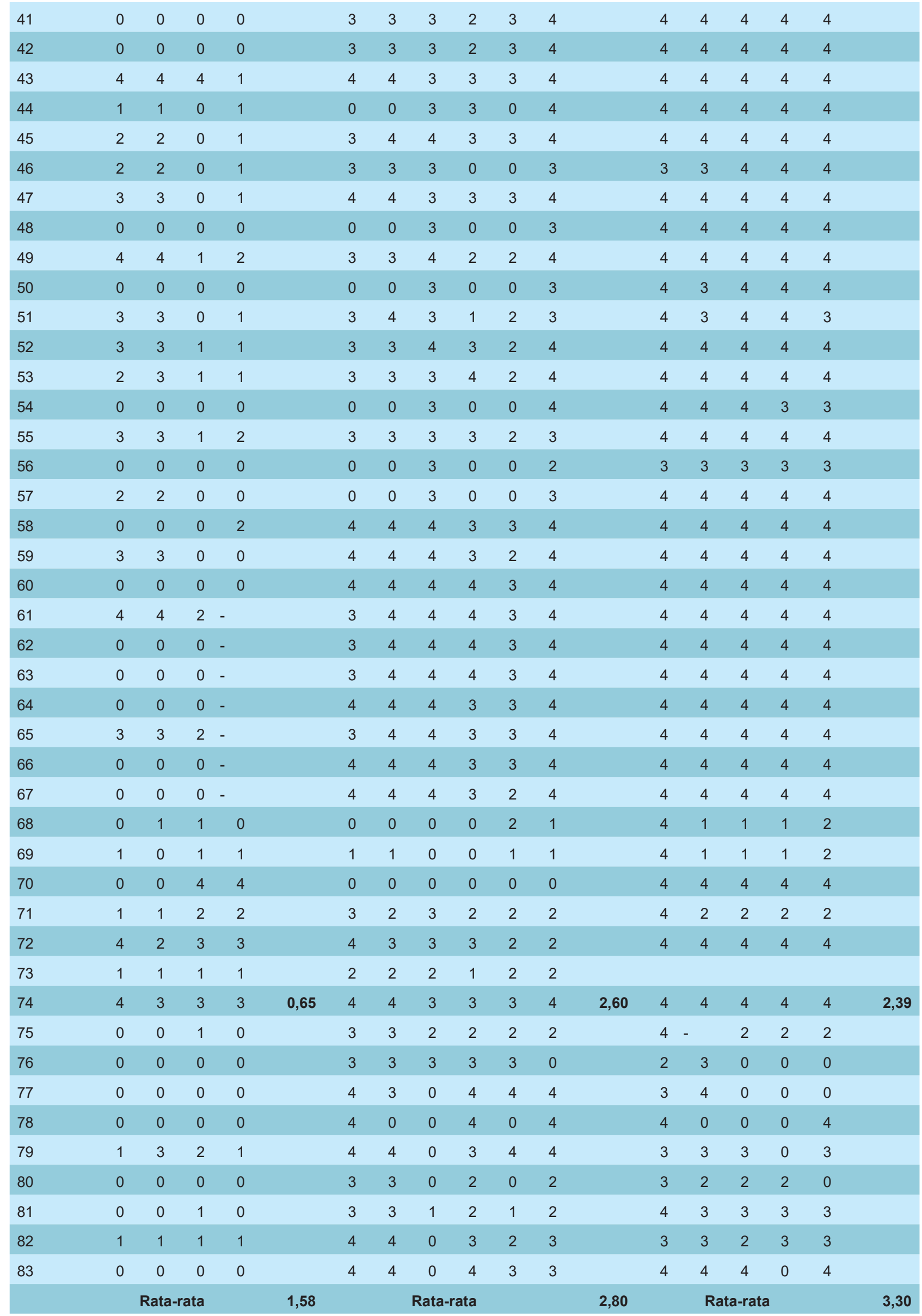


Keterangan skor :

$\begin{array}{ccccc}0 & 1 & 2 & 3 & 4 \\ \text { sangat tidak sesuai } & \text { tidak sesuai } & \text { agak sesuai } & \text { Sesuai } & \text { sangat sesuai }\end{array}$

Berdasarkan tabel di atas selanjutnya dibuat grafik untuk memahami dan menganalisis data secara lebih mudah. Grafik yang diperoleh dari data tersebut dapat dilihat di Grafik 1.

Berdasarkan grafik di atas dapat dilihat perbedaan sikap antara kelompok responden. Dari ketiga kelompok responden di atas kelompok staf otoritas APSARA memiliki pengetahuan yang paling tinggi (skor 2,5), karena mereka merupakan pegawai yang bekerja di pelestarian kawasan Angkor sehingga mengetahui setiap proyek yang pernah dan sedang dikerjakan. Sedang kelompok responden wisatawan asing memiliki skor pengetahuan yang sangat rendah. Hal ini perlu mendapat perhatian karena responden merupakan wisatawan yang sedang berkunjung di area Royal Palace. Hal ini menunjukkan bahwa informasi yang ada sangat tidak memadai, ruang informasi Indonesia yang ada belum berfungsi secara optimal. Hal ini perlu menjadi perhatian dalam pelaksanaan proyek ke depan. Untuk masyarakat lokal tergantung pada domisili dan aktivitasnya, untuk yang jauh dari area Royal Palace kurang mengetahui.

Untuk persepsi berada pada kisaran yang relatif tidak berbeda jauh (skor antara 2,60-2,91). Skor ini relatif cukup tinggi dan merata untuk semua kelompok responden. Hal ini cukup menggembirakan karena menunjukkan bahwa hasil pemugaran yang telah dilaksanakan sekitar 15 tahun lalu masih dinilai baik oleh para responden. Hasil merupakan penilaian objektif dan dapat menjadi gambaran keberhasilan proyek yang telah dilaksanakan.

Dukungan terhadap proyek bantuan pemugaran di kawasan Angkor termasuk keterlibatan Indonesia juga memiliki nilai yang tinggi. Untuk kelompok responden

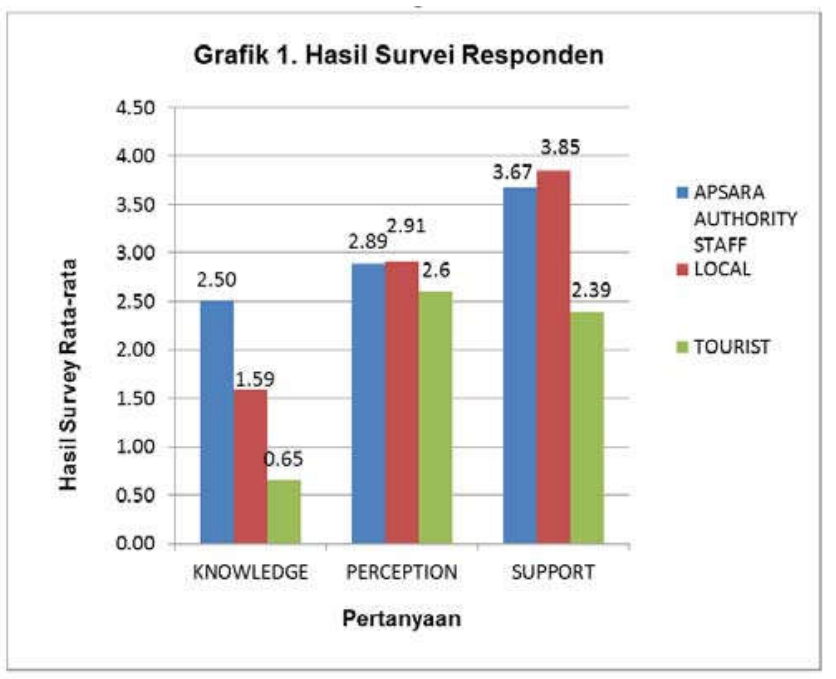

wisatawan asing nilai relatif lebih rendah $(2,39)$ meskipun masih cukup baik. Hal ini disebabkan Indonesia belum dipandang sebagai negara yang terkemuka dalam kegiatan pelestarian cagar budaya di tingkat dunia. Sedangkan untuk kelompok responden staf otoritas APSARA dan masyarakat lokal nilai dukungan sangat tinggi (3,67 dan 3,85). Untuk pihak otoritas APSARA, adanya bantuan internasional sangat diharapkan karena banyaknya permasalahan konservasi yang dihadapi sementara sumber daya yang ada kurang memadai. Untuk masyarakat lokal, skor tinggi ini sebagian besar disebabkan karena faktor kebutuhan akan kesempatan pekerjaan. Dengan adanya proyek yang dilaksanakan maka ada kebutuhan tenaga, dimana masyarakat lokal dapat terlibat di dalamnya.

Pada saat menjawab pertanyaan dalam kuisioner, responden juga diminta memberikan komentar dan masukan berkenaan dengan tindak lanjut ke depan. Sebagian responden bersedia mengisi, dan sebagian lainnya tidak mengisi. Masukan dan komentar yang diberikan oleh responden yang mengisi adalah sebagai berikut.

Tabel 4. Komentar dan Masukan Responden Terhadap Tindak Lanjut

\begin{tabular}{|c|c|}
\hline $\begin{array}{c}\text { Nomor } \\
\text { Respoden }\end{array}$ & Komentar atau Masukan \\
\hline 1 & $\begin{array}{l}\text { Menyarankan restorasi dan konservasi ke depan yang dilakukan kawasan Royal Palace seperti gerbang } \\
\text { yang lainnya atau candi. }\end{array}$ \\
\hline 2 & Proyek ITASA dilanjutkan, pemugaran ke depan di kawasan Royal Palace, Angkor Thom \\
\hline 3 & $\begin{array}{l}\text { Terus melakukan restorasi di stus Angkor karena tim dari Indonesia proyek ITASA sangat memberikan } \\
\text { pengalaman bagi Kamboja. Pengetahuan yang diperoleh dapat dibagikan kepada tim yang lain di masa } \\
\text { yang akan datang. Sangat mendukung apabila proyek ITASA dilanjutkan kembali di situs Angkor. }\end{array}$ \\
\hline 4 & Proyek ITASA kedepan untuk mengembangkan analisis laboratorium batu di Kamboja. \\
\hline
\end{tabular}




\begin{tabular}{|c|c|}
\hline 5 & Proyek ITASA ke depan untuk melakukan pemugaran Candi Phi Mean Akas di Situs Royal Palace \\
\hline 6 & Proyek jangka pendek adalah mengembalikan batu yang belum terpasang ke lokasi aslinya. \\
\hline 7 & Proyek ITASA ke depan untuk pemugaran Candi Bata \\
\hline 8 & $\begin{array}{l}\text { Proyek ITASA sebelumnya telah melatih } 5 \text { expert dari Kamboja dan semuanya bisa mengembalikan } \\
\text { monument kuno di Kamboja dan itu merupakan proyek terbaik }\end{array}$ \\
\hline 9 & Berharap membantu proyek pemugaran di Angkor Thom dan berharap dapat belajar. \\
\hline 10 & $\begin{array}{l}\text { Berharap di lanjutkan proyek pemugaran untuk semua candi dan berharap dapat bergabung proyek } \\
\text { selanjutnya. }\end{array}$ \\
\hline 11 & $\begin{array}{l}\text { Berharap melanjutkan proyek pemugaran di Kamboja dan dapat bertukar pengalaman dengan expert } \\
\text { Khmer. }\end{array}$ \\
\hline 12 & Berharap proyek dilanjutkan di Kamboja. Dan berharap dapat belajar dari proyek pemugaran. \\
\hline 13 & $\begin{array}{l}\text { Berharap proyek ITASA dilanjutkan kembali di Kamboja dan dapat bertukar pengalaman dengan staff } \\
\text { Kamboja }\end{array}$ \\
\hline 14 & ITASA dapat lebih melatih staff Kamboja sehingga staff dari Kamboja dapat memugar candi. \\
\hline 16 & $\begin{array}{l}\text { Tidak tahu tim ITASA yang lalu tetapi senang apabila tim sekarang kembali lagi sehingga dapat membantu } \\
\text { Khmer untuk pekerjaan restorasi. Rekomendasi untuk menangani Candi Bata di situs Angkor, seperti Pre } \\
\text { Rup, Bat Chum, dll }\end{array}$ \\
\hline 19 & $\begin{array}{l}\text { Berharap ada kelanjutan dari Proyek ITASA karena proyek tersebut memberikan pengalaman dalam } \\
\text { restorasi. Merekomendasikan untuk pemugaran Candi Bata karena mereka belum berpengalaman } \\
\text { pemugaran Candi Bata. }\end{array}$ \\
\hline 20 & $\begin{array}{l}\text { Pengalaman bekerja dengan ITASA memberikan kesempatan yang baik untuk meningkatkan kapasitas, } \\
\text { harapan proyek ITASA terus dilanjutkan. Rekomendasi untuk membuat proyek di situs Angkor Wat (di luar } \\
\text { kompleks), khususnya untuk Candi Bata. }\end{array}$ \\
\hline 21 & $\begin{array}{l}\text { ITASA memberikan pelatihan yang sangat baik, jika mungkin untuk melanjutkan proyek di masa depan. } \\
\text { Rekomendasi proyek ke depan di luar situs Angkor. Contohnya Candi Bata. }\end{array}$ \\
\hline 22 & $\begin{array}{l}\text { Berharap proyek ITASA dilanjutkan kembali, karena ingin melihat pemugaran Royal Palace selesai. } \\
\text { Rekomendasi ke depan pemugaran Candi Bata. }\end{array}$ \\
\hline 23 & $\begin{array}{l}\text { Teknik restorasi Indonesia menyimpan jejak. Rekomendasi proyek ITASA dilanjutkan untuk memberikan } \\
\text { warga lokal pekerjaan dan ITASA dapat melakukan proyek pemugaran di luar situs Angkor. }\end{array}$ \\
\hline 24 & Setuju ITASA dilanjutkan. Proyek ke depan dekat Royal Palace \\
\hline 25 & Setuju ITASA dilanjutkan. \\
\hline 26 & Berharap proyek ITASA dapat dilanjutkan, Proyek ITASA ke depan di luar Royal Palace. \\
\hline 27 & $\begin{array}{l}\text { Sangat senang apabila proyek ITASA dapat dilanjutkan. Rekomendasi proyek pemugaran ke depan adalah } \\
\text { Candi Baly Lied dan } 2 \text { pintu gerbang yang lain belum dipugar. }\end{array}$ \\
\hline 29 & $\begin{array}{l}\text { Proyek selanjutnya harus mengikuti rekomendasi internasional dan berkomunikasi dengan dengan utusan } \\
\text { internasional yang lainnya. Rekomendasi untuk proyek selanjutnya Candi Phimenakas }\end{array}$ \\
\hline 30 & Teknik restorasi dan reservasi harus sesuai dengan rekomendasi pakar internasional. \\
\hline 33 & $\begin{array}{l}\text { Proyek ITASA dilanjutkan sehingga memberi lapangan pekerjaan. Lokasi selanjutnya yang dekat dengan } \\
\text { pusat turis. }\end{array}$ \\
\hline 46 & Kamboja memerlukan pelatihan tentang pemugaran dan konservasi candi. \\
\hline 58 & Berharap proyek ITASA berlanjut dan fokus pada konsolidasi dan stabilisasi bata di Kamboja. \\
\hline 69 & $\begin{array}{l}\text { Sangat senang kepada Indonesia melalui proyek ITASA tahun } 1995-2000 \text { yang telah membantu pekerjaan } \\
\text { restorasi pada gerbang Royal Palace di Angkor Thom dan sangat berharap kerjasama antara Indonesia } \\
\text { dengan Kamboja akan bertahan dalam jangka panjang pada setiap proyek. }\end{array}$ \\
\hline 74 & Pertanyaan tidak spesifik untuk turis \\
\hline 75 & Pekerjaan yang bagus, terus lakukan \\
\hline
\end{tabular}

\section{Kunjungan Ke APSARA Authority}

Kunjungan ke APSARA Authority bertujuan untuk mengetahui bagaimana tanggapan otoritas APSARA terhadap proyek yang pernah dilaksanakan oleh Indonesia, melalui diskusi dan wawancara. Wawancara dengan pimpinan dan staf otoritas APSARA diperlukan karena saat ini APSARA merupakan otoritas yang memiliki kewenangan dalam semua pengelolaan dan pelestarian kawasan angkor. Hasil wawancara memberikan informasi bahwa APSARA Autbority memberikan catatan positif terhadap proyek yang dilaksanakan oleh Indonesia, salah satunya adalah bahwa 4 orang tenaga teknisi yang dahulu dididik pada saat proyek ITASA saat ini merupakan tenaga inti pelestarian di APSARA Authority dan Kementerian Kebudayaan Kamboja, bahkan mereka menempati posisi jabatan penting. Wawancara juga menyatakan bahwa APSARA masih berharap Indonesia dapat kembali melaksanakan proyek di Kamboja, dan siap untuk bekerjasama sesuai aturan yang ada. 


\section{Kunjungan Ke Beberapa Proyek yang sedang Berjalan}

Pada saat kunjungan juga dilakukan pengamatan terhadap beberapa proyek yang dikerjakan oleh negaranegara lain pada beberapa candi di kawasan Angkor. Karena kunjungan cukup singkat maka hanya bisa
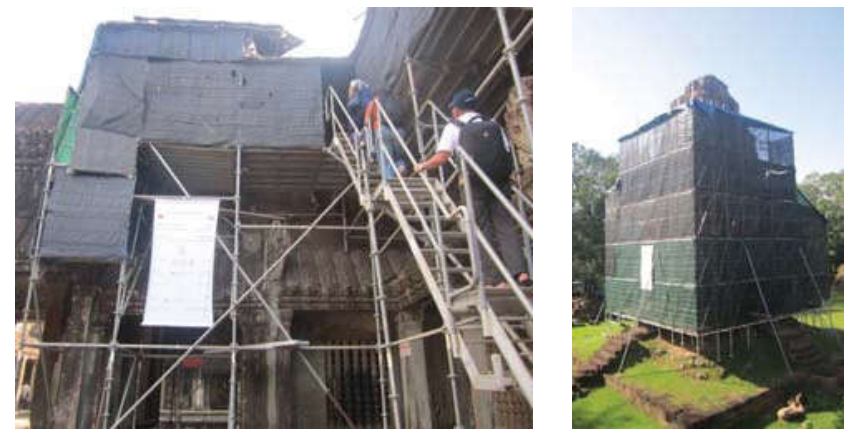

Konservasi dan Pemugaran di Angkor Wat dan Bakong oleh Jerman

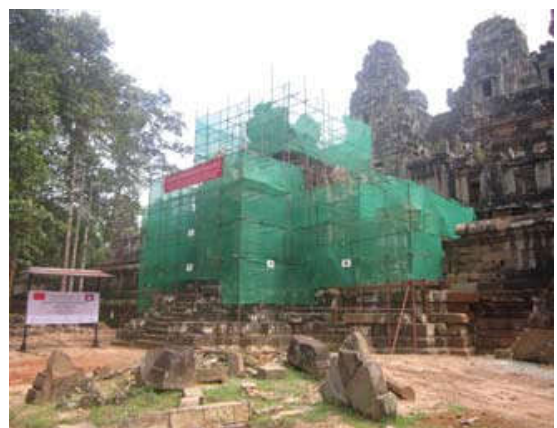

Pemugaran Ta Keo oleh China
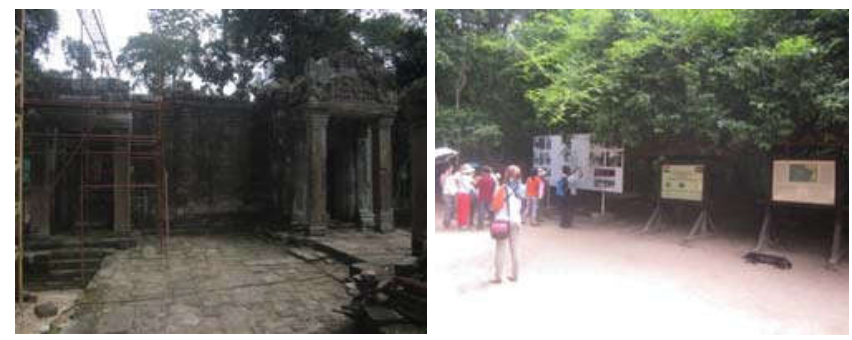

Pemugaran Ta Phrom oleh India

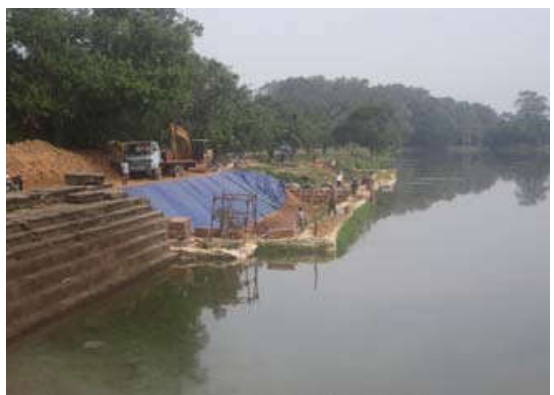

Pemugaran Dinding Kolam Angkor Wat oleh Italia mengidentifikasi, namun tidak mendapatkan informasi yang mendalam mengenai proyek yang sedang dikerjakan. Berikut ini beberapa situs yang sedang dipugar/ dikonservasi dengan proyek dari luar negeri dan proyek oleh otoritas APSARA sebagai pembanding.
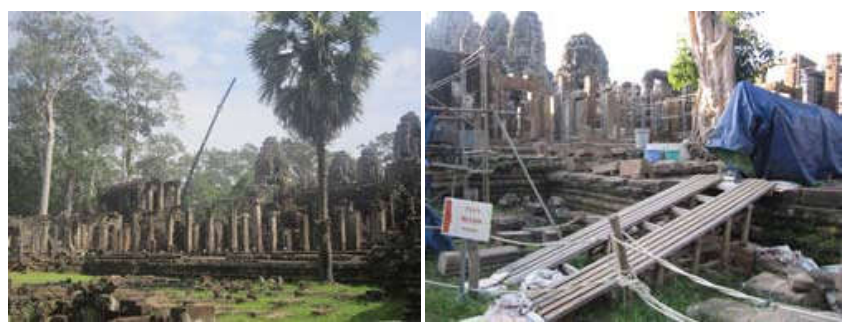

Pemugaran Bayon oleh Jepang

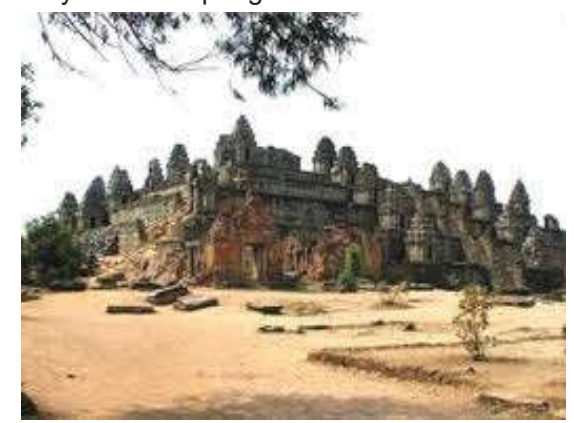

Pemugaran Bakheng oleh Amerika Serikat

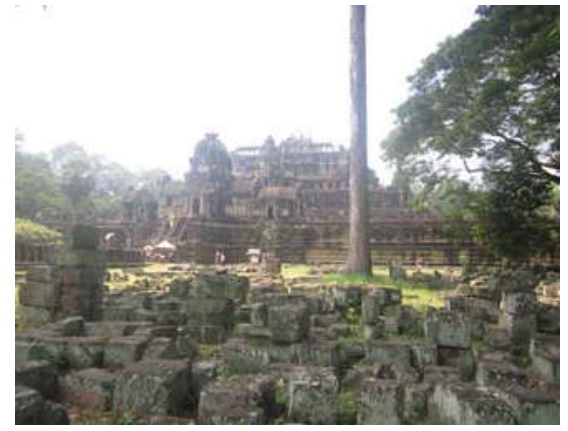

Eks Pemugaran Bapuon oleh Perancis

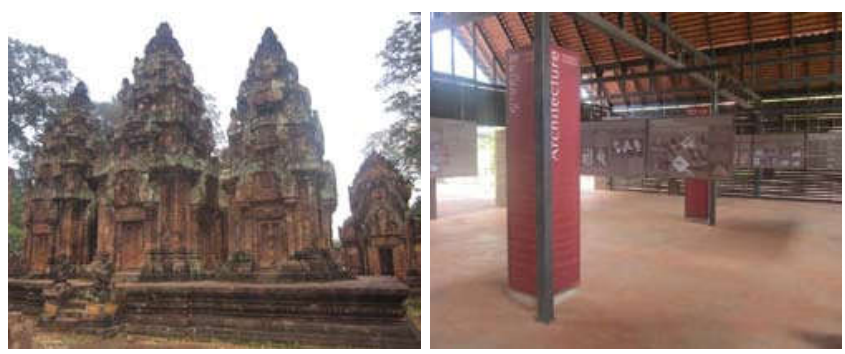

Hasil Pemugaran dan Ruang Informasi di Banteay Srei oleh Swiss

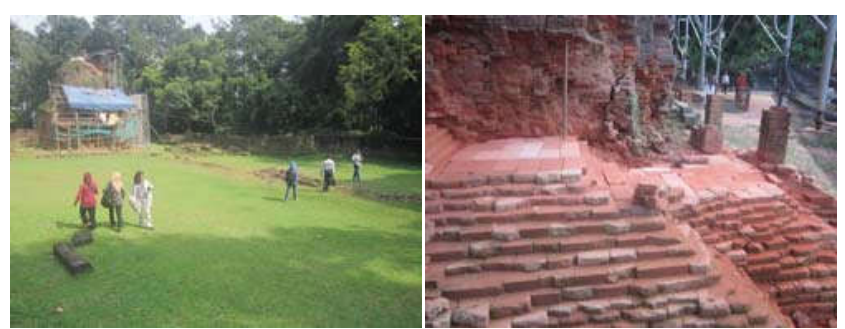

Pemugaran Preah Ko dan Lolei oleh APSARA Authority 


\section{E. Diskusi Hasil Monitoring Dan Evaluasi Pemugaran Royal Palace Angkor Thom Kamboja (TAHAP I)}

Kegiatan diskusi ini dilaksanakan selama 1 hari yaitu pada tanggal 28 Januari 2015 dengan melibatkan berbagai pemangku kebijakan antara lain Dirjen Kebudayaan, Direktur PCBM, Direktur INDB, Direktur PT.TWCBP, Eks Proyek ITASA. Adapun tujuan diadakannya diskusi ini adalah untuk mendapatkan masukan mengenai langkah ke depan apakah perlu dilanjutkan kembali program ITASA 2. Kegiatan diskusi ini diawali dengan paparkan hasil monitoring dan evaluasi yang telah dilaksanakan di Kamboja pada tanggal 12-19 Oktober 2014 selanjutnya tanggapan dari berbagai pemangku kebijakan. Berdasarkan hasil diskusi ini diperoleh masukan apabila proyek pemugaran ITASA Tahap 2 dilaksanakan kembali maka harus memperhatikan kepentingan (urgency dan keuntungan) serta diperlukan perencanaan sebaik-baiknya dengan memperhatikan kemampuan SDM, metode, teknik dan teknologi yang digunakan dalam melakukan pemugaran. Diharapkan bentuk kerjasama harus jelas sehingga tidak merugikan kedua belah pihak. Dari diskusi ini juga diperoleh masukan bahwa ke depan perlu dipelajari pengelolaan monumen dan pemberdayaan masyarakat di Angkor Wat Kamboja yang berjalan cukup baik sehingga bisa dijadikan bahan pertimbangan dalam pengelolaan di Candi Borobudur.

\section{PENUTUP}

Berdasarkan monitoring dan evaluasi hasil pemugaran Royal palace Angkor Thom Kamboja (Tahap I) maka diperoleh kesimpulan dan saran sebagai berikut :

\section{A. Kesimpulan}

Kesimpulan yang dapat diambil dari kajian ini adalah :

1. Hasil pemugaran Indonesia melalui proyek ITASA yang telah berumur kurang lebih 15 tahun saat

\section{DAFTAR PUSTAKA}

Freeman M, Jacques C, (2003, reprint 2013), Ancient Angkor, River Books, Bangkok

Sedyawati Edi, IGN Anom, Nunus Supardi, Samidi, Djasponi(2000), Report of ITASA in ini masih dalam kondisi yang baik. Beberapa permasalahan yang terjadi masih dalam batas yang wajar karena material candi memiliki kerentanan dalam kondisi lingkungan yang ada.

2. Tingkat pengetahuan masyarakat Kamboja dan staf otoritas APSARA terhadap proyek yang pernah dilaksanakan Indonesia cukup baik, sedangkan wisatawan asing sangat rendah. Sistem informasi yang ada perlu ditingkatkan untuk memberikan informasi kepada penunjung secara efektif.

3. Secara umum masyarakat dan wisatawan memberikan apresiasi yang cukup baik terhadap hasil pemugaran oleh Indonesia. Dukungan terhadap bantuan internasional pada pemugaran situs-situs di Angkor termasuk oleh Indonesia cukup tinggi.

4. Proyek pelestarian yang dilaksanakan oleh masyarakat internasional dari berbagai negara masih berlangsung secara intensif hingga saat ini. Pemerintah Kamboja dan APSARA Authority masih berharap adanya proyek dari masyarakat internasional.

B. Saran

Saran yang dapat diberikan adalah sebagai berikut :

1. Perlu dilakukan kajian yang lebih mendalam mengenai perlunya keterlibatan kembali Indonesia dalam proyek pemugaran di Angkor. Perlu dikaji secara mendalam mengenai keuntungan dan kerugian keterlibatan pemerintah Indonesia.

2. Kajian ini juga perlu diikuti dengan perencanaan teknis dan diplomasi antar negara dengan sebaik mungkin. Perencanaan yang lebih mendalam diperlukan dengan memperkaya dengan data lapangan serta pertemuanpertemuan diplomasi, baik dengan otoritas Kamboja maupun negara-negara lain yang selama ini terlibat.

Safeguarding Royal Palace Site, Volume I : Introduction, Directorate General for Culture, Departement of National Education Building E, $4^{\text {th }}$ Floor 
Report of ITASA in Safeguarding Royal Palace Site, Volume II : Restoration of South Tower Gate I of The Royal Palace Site, April $15^{\text {th }}$, 1995- April 15 ${ }^{\text {th }}, 1996$, Directorate General for Culture, Departement of National Education Building E, $4^{\text {th }}$ Floor

Report of ITASA in Safeguarding Royal Palace Site, Volume III : Restoration of North Tower Gate I of The Royal Palace Site, April $15^{\text {th }}$ ,1996- July $15^{\text {th }}, 1996$, Directorate General for Culture, Departement of National Education Building E, $4^{\text {th }}$ Floor

Report of ITASA in Safeguarding Royal Palace Site, Volume II : Restoration of East
Main Tower Gate of The Royal Palace Site, September $15^{\text {th }}, 1997-$ March $31^{\text {th }} ， 2000$, Directorate General for Culture, Departement of National Education Building E, $4{ }^{\text {th }}$ Floor

Soekmono, (1974), Candi, Fungsi dan Pengertiannya, Disertasi untuk Gelar Doktor dalam Ilmu-Ilmu Sastra Universitas Indonesia

Utomo, Bambang Budi, (2013), Warisan Dinasti Sailendra di Asia Tenggara, Belahan Barat Nusantara, Makalah pada Kongres Kebudayaan Indonesia 2013 Yogyakarta 